\title{
The results of 100 small tissue biopsies of testis in male infertile patients
}

\author{
R. SCOTT \\ M.B., Ch.B., F.R.C.S. \\ J. SinCLAIR \\ A. RourKe \\ M.B., Ch.B. \\ M.B., Ch.B., F.R.C.S. \\ A. Yates \\ M.B., Ch.B., F.R.C.S. \\ S. CHOWDHURY \\ F.R.C.S. \\ J. SHABA* \\ M.B., Ch.B., M.R.C.Path. \\ Department of Urology, and *Department of Pathology, Royal Infirmary, Glasgow
}

\begin{abstract}
Summary
The value of testicular biopsy in male infertility has recently been emphasized by Meinhard, McRae and Chisholm (1973), and the present authors agree with them that a biopsy is essential for the following reasons: (1) to establish a firm diagnosis; (2) to rationalize therapy on the basis of histological findings; (3) new developments in drug therapy and electronmicroscopic techniques will help to clarify many areas of doubt and uncertainty in this difficult field; (4) the diagnosis of 'sloughing' by itself may mask changes in germinal cell development which may be amenable to hormone therapy.
\end{abstract}

\section{Introduction}

Certain patients require testicular biopsy if rational drug therapy is to be employed in the treatment of male infertility (Markewitz et al., 1968; Girgis et al., 1969). Advances in hormone therapy can be expected to develop parallel with research into drugs that regulate the reproductive cycle in women. The histological findings in 100 small tissue biopsies undertaken in the Department of Urology, Glasgow Royal Infirmary, between 1970 and 1972 are presented. The results are related to semen analysis and aetiological factors.

\section{Materials and methods}

Patients referred to the male infertility clinic were examined with respect to general physical state, genital development and serology. A seminal specimen was obtained by coitus interruptus and if two consecutive counts were below $20 \times 10^{6}$ sperms $/ \mathrm{ml}$ or had less than $45 \%$ motile sperms at $2 \mathrm{hr}$, the patient was advised to have a testicular biopsy. Under general anaesthesia, the scrotal skin was stretched over the testis and a stab biopsy undertaken (Charny, 1956), the specimen being fixed

Requests for reprints: Mr R. Scott, F.R.C.S., Department of Urology, Glasgow Royal Infirmary. immediately in Bouin's fluid. Infertile patients undergoing operation for varicocele, hydrocele or undescended testis were treated similarly. If the biopsy report revealed sloughing of the germinal epithelium with lumenal blockage the patients were treated with sublingual methyl testosterone $15 \mathrm{mg}$ t.i.d. for 3 months and a further seminal analysis undertaken. Patients with azoospermia who had, on biopsy, evidence of normal sperm production were considered for epididymovasostomy. Those with germinal cell arrest were referred to the Endocrine Clinic for gonadotrophin assays and therapy if indicated.

\section{Results \\ Histological findings}

The histological findings of the 100 consecutive biopsies are shown in Table 1. The failed biopsy occurred in a patient with small testes, the specimen containing only epididymal tissue.

Of the seventy-six patients in whom sloughing was reported in the testicular biopsy, twenty-five were noted to have associated disorderly maturation.

There were four patients with maldescended testes. In three who underwent orchidopexy the biopsy of the contralateral testis in which there was no history of delayed descent showed the 'Sertoli Cell Only' appearance, while in the fourth, who had an orchidectomy, the contralateral testis showed the features of sloughing.

\section{Findings on seminal analysis}

Twenty-nine patients of the series had azoospermia, but in only two of these was the histology normal. Five of this group had the Sertoli Cell Only appearance, one germinal cell arrest, three Klinefelter's syndrome. The remaining eighteen had sloughing of varying degree which in five cases was associated with disorderly spermatogenesis and in a further five with spermatogenic arrest. The seminal 
TABLE 1. Results of 100 consecutive testicular biopsies

\begin{tabular}{lr}
\hline Normal & 3 \\
Sertoli cell only syndrome & 12 \\
Germinal cell arrest & 8 \\
Sloughing of germinal epithelium & 51 \\
$\begin{array}{l}\text { Sloughing of germinal epithelium } \\
\quad \text { with disorderly maturation }\end{array}$ & 25 \\
Failed & 1 \\
& 100 \\
\hline
\end{tabular}

TABLE 2. Seminal analysis in seventy-six cases with sloughing

\begin{tabular}{lrlr}
\hline \multicolumn{1}{c}{ Sperm density } & \multicolumn{2}{c}{ Motility at $2 \mathrm{hr}$} \\
\hline $30-40 \times 10^{6} / \mathrm{ml}$ & 5 & $>40 \%$ & 5 \\
$20-30 \times 10^{6} / \mathrm{ml}$ & 10 & $30-40 \%$ & 6 \\
$<20 \times 10^{6} / \mathrm{ml}$ & 43 & $<30 \%$ & 34 \\
Azoospermia & 18 & 0 & 31 \\
& - & & 76 \\
& 76 & & - \\
\hline
\end{tabular}

analysis of the seventy-six patients with sloughing is shown in Table 2. Forty-three had sperm densities below $20 \times 10^{6} / \mathrm{ml}$, but none of the seventy-six had a motility figure of greater than $50 \%$ at $2 \mathrm{hr}$.

Possible aetiological factors in the patients with germinal cell arrest and the Sertoli Cell Only syndrome are shown in Tables 3 and 4 respectively. In the total series, twenty-six patients gave a past history of mumps and, of these, four had the Sertoli Cell Only syndrome and four showed the features of germinal cell arrest. Seven of this group presented with azoospermia. The remaining eighteen demonstrated sloughing, which in six cases was accompanied by disorderly spermatogenesis.

TABLE 3. Possible aetiological factors in eight patients with germinal cell arrest

\begin{tabular}{lr}
\hline Past history of mumps & 3 \\
Varicocele & 2 \\
Mumps and varicocele & 1 \\
None & 2 \\
& -8 \\
\hline
\end{tabular}

TABle 4. Possible aetiological factors in twelve patients with Sertoli Cell Only syndrome

\begin{tabular}{ll}
\hline Past history of mumps & 4 \\
$\begin{array}{l}\text { Undiagnosed undescended testis } \\
\text { Klinefelter's syndrome }\end{array}$ & 4 (1 bilateral) \\
$\begin{array}{l}\text { Previous inguinal herniotomy in } \\
\text { the first year of life }\end{array}$ & 3 \\
& 1 \\
\hline
\end{tabular}

\section{Results of subsequent treatment}

Epididymovasostomy was offered to the two azoospermia patients with normal histology. One refused and the other still had azoospermia following surgery. A further three patients with mild sloughing and azoospermia were offered surgery and unsuccessful epididymovasostomy carried out in two, the third on exploration having an apparently patent vas deferens. The primary management of the eight patients with germinal cell arrest was to treat those with histological evidence of some sloughing with testosterone. Two of the remaining three were treated with human menopausal chorionic gonadotrophin (HMG) but neither of these patients showed any subsequent increase in sperm density, although the motility figures increased from an average of $2 \%$ to $38 \%$ and $0 \%$ to $21 \%$ respectively.

A variable sized varicocele was noted in fourteen patients, five of whom underwent operation where it was thought to be a significant factor. Of these five, two had a subsequent 3-month course of methyl testosterone. The sperm density and motility of the group is shown in Table 5. One of the fourteen patients had azoospermia and testicular biopsy showed sloughing with tubular hyalinization. He received no therapy. A further patient had a severe degree of maturation arrest and received a course of gonadotrophin which increased motility of the spermatozoa from 0 to $21 \%$ but did not alter his sperm density. The remaining seven patients allọ showed sloughing on biopsy and as the varicocele? was small, were treated with methyl testosterone alone. Two of the seven showed associated disorderly spermatogenesis, and one a minor degree of maturation arrest.

\section{Discussion}

Testicular biopsy is being re-evaluated as a step in the investigation of infertility (Garduno and Mehan, 1970; Nelson, 1952; Dubin and Hotchkiss, 1969; Girgis et al., 1969; Markewitz et al., 1968). The criteria used in selecting patients for biopsy must be carefully defined (Garduno and Mehan, 1970). The Sertoli Cell Only appearance, characterized by small tubules without germinal epithelium and without peritubular fibrosis or an increase in Leydig cells, is thought to be congenital in many cases, although four of the twelve cases gave a past history of mumps. A further four had a past history of undescended testis and it may be that the normally placed contralateral testis may also be histologically abnormal (Table 4). No known treatment can be of any avail in such patients.

Germinal cell arrest usually occurs at the primary spermatocyte stage, the seminiferous tubules being otherwise normal. The aetiology of this condition is ill understood although a previous history of pyrexial 
TABLE 5. Patients with varicocele who underwent ligation

\begin{tabular}{|c|c|c|c|c|}
\hline & $\begin{array}{c}\text { Pre-treatment } \\
\text { density } \\
\left(10^{6} / \mathrm{ml}\right)\end{array}$ & $\begin{array}{c}\text { Postoperative } \\
\text { density } \\
\left(10^{6} / \mathrm{ml}\right)\end{array}$ & $\begin{array}{l}\text { Pre-treatment } \\
\text { motility } \\
(\%)\end{array}$ & $\begin{array}{c}\text { Postoperative } \\
\text { motility } \\
(\%)\end{array}$ \\
\hline \multicolumn{5}{|l|}{ No androgen therapy } \\
\hline (1) & $15 \cdot 5$ & $9 \cdot 7$ & 0 & 38 \\
\hline (2) & $2 \cdot 1$ & $4 \cdot 5$ & 0 & 1 \\
\hline (3) & 0 & $3 \cdot 5$ & 0 & $3 \cdot 3$ \\
\hline \multicolumn{5}{|l|}{ Androgen therapy } \\
\hline (4) & $2 \cdot 1$ & $\begin{array}{l}14 \cdot 7 \\
60 \text { (after } \\
\text { androgen } \\
\text { therapy) }\end{array}$ & 23 & $\begin{array}{l}36 \\
50 \text { (after } \\
\text { androgen } \\
\text { therapy) }\end{array}$ \\
\hline (5) & $33 \cdot 6$ & $\begin{array}{l}14 \cdot 1 \\
62 \text { (after } \\
\text { androgen } \\
\text { therapy) }\end{array}$ & 15 & $\begin{array}{l}31 \\
31 \text { (after } \\
\text { androgen } \\
\text { therapy) }\end{array}$ \\
\hline
\end{tabular}

illness or working in a hot environment have been incriminated (Nelson, 1953). The primary spermatocytes often slough into the lumen, and this phenomenon was seen in five of the eight cases. Two cases without sloughing were given treatment with HMG, the follicle stimulating hormone (FSH) of which has been shown to assist maturation of spermatids to fully mature spermatozoa (Gemzell and Kjessler, 1964). The transformation of spermatogonia to spermatid is considered by some authorities to be autonomous. Macleod, Pazianos and Ray (1964), however, feel that this step in maturation is activated by HMG. Mroueh, Lytton and Kase (1967), investigating nineteen males with oligospermia, found a doubtful improvement in the count and motility in only two cases after HMG, although the seminal fluid volume was increased. They assessed steroid excretion by measuring urinary gonadotrophic hormones, testosterone, 17-ketosteroids and 17ketogenic steroids and total urinary oestrogens. They found that enhanced excretion of these products was not accompanied by improved tubular function. Only one patient in the present series was found to have an increase in the number of spermatids and spermatozoa following HMG.

Sloughing of the germinal epithelium is characterized by the presence of immature spermatogenic cells in the lumenal contents. Disturbance of orderly spermatogenesis in the basal cell layers may be found accompanying this sloughing. An increase in peritubular fibrosis and intercellular collagen is not necessarily a feature of this condition. Some precursors do mature to sperm, and account for the spermatozoa in the ejaculate. Patients in the present series, with sloughing in the testicular biopsy, were usually treated by methyl testosterone administration in an attempt to suppress sperm production so that continued ejaculation allowed the slough to clear from the lumen of the tubules. It was hoped that a 'rebound phenomenon' (Heller et al., 1950) would occur but this rarely happened. At best, only $37 \%$ of patients can be expected to produce a pregnancy following methyl testosterone therapy (Heckel and McDonald, 1952; Harvey and Jackson, 1957). In the present series, fifty-four were treated with $5 \mathrm{mg}$ methyl testosterone, thrice daily for 3 months. The improvement in density and motility was minimal at 3 months. Pre-treatment values improved by an average of only $2 \times 10^{6} \mathrm{sperm} / \mathrm{ml}$ in this time. Motility improved by $4 \%$ on average. Only two reported a pregnancy within 6 months of therapy but many defaulted or became lost to follow-up. Spence and Medvei (1959) emphasized that a rebound phenomenon does not always occur, and that permanent suppression of spermatogenesis may ensue, although this was not found in the present series. Rowley and Heller (1972), however, emphasized the importance of achieving complete azoospermia with methyl testosterone in the absence of urinary gonadotrophins. He found complete recovery to pre-treatment levels by 6-18 months, and noticed that conception often occurred before this was achieved. Girgis et al. (1969) in more than 800 patients considered the cause of azoospermia to be functional rather than mechanical in $46 \%$ of cases. In the present series, however, only two of twentynine patients were found to have normal histological features. Twenty-eight of the twenty-nine, or almost $100 \%$ were found to have a functional dysplasia of the germinal epithelium.

Tulloch (1952) first demonstrated hypospermatogenesis with maturation arrest in patients with varicoceles, and Scott $(1958 ; 1961)$ showed that this was the commonest finding on testicular biopsy. Etriby et al. (1967) found that thirty-two $(50 \%)$ of a series of sixty-four cases had counts below $1000 / \mathrm{ml}$, while the other thirty-two $(50 \%)$ had a variable oligospermia. On testicular biopsy of the latter, 
eighteen were found to have germinal cell arrest, sixteen at the spermatid stage, and two at the primary spermatocyte stage. In the present series, only two of fourteen patients $(14 \%)$ showed maturation arrest. In the former series eleven $(16 \%)$ showed sloughing with disorderly spermatogenesis as compared with two $(14 \%)$ in the small series. Three of the patients with varicocele had the Sertoli Cell Only syndrome while there was none in the larger series.

\section{Testicular size}

Twenty of the 100 patients were noted to have small testes, sixteen being bilateral. In fifteen, the testicular biopsy revealed sloughing which in four cases was accompanied by disorderly spermatogenesis, and two of these four had one small testis only. Six of this group were treated with methyl testosterone, and in only two was there marginal improvement. Five of these patients were azoospermic. Four of the patients with bilateral small testes had the Sertoli Cell Only syndrome and one patient had Klinefelter's syndrome.

\section{References}

Charny, C.W. (1956) Treatment of male infertility with large doses of testosterone. Journal of the American Medical Association, 160, 98.

Dubin, L. \& Hotchkiss, R. (1969) Testis biopsy in subfertile men with varicocele. Fertility and Sterility, 20, 50.

Etriby, A., Girgis, A.M., Hefnawy, H. \& Ibrahim, A.A. (1967) Testicular changes in sub-fertile males with varicocele. Fertility and Sterility, 18, 666.

Garduno, A. \& Mehan, D.J. (1970) Testicular biopsy findings in patients with impaired fertility. Journal of Urology, 104, 871.

Gemzell, C. \& KJessler, B. (1964) Treatment of infertility after hypophysectomy with human menopausal gonadotrophins. Lancet, i, 644.
Girgis, S.M., Etriby, A., Ibrahim, A.A. \& Kahil, S.A (1969) Testicular biopsy in azoospermia. Fertility and Sterility, 20, 467.

HARVEY, C. \& JACKSON, H. (1957) Intermittent methyl testosterone therapy in male infertility. Lancet, $\mathbf{i}, 711$.

HeCKel, N.J. \& McDonald, J.H. (1952) The rebound phenomenon of the spermatogenic activity of the human testis following the administration of testosterone propionate. Fertility and Sterility, 3, 49.

Heller, G.G., Nelson, W.O., Hill, I.B., Henderson, E., Maddock, W.O., Jungck, E.C., Poulsen, C.A. \& MortiMORE, G.E. (1950) Improvement in spermatogenesis following depression of the human testis with testosterone. Fertility and Sterility, 1, 415.

Markewitz, M., Sommers, S.C., Veenema, R.J. \& Butler, M.D. (1968) Testicular biopsy artefacts resulting from improper tissue processing. Journal of Urology, 100, 44.

Meinhard, E., MCRae, C.U. \& Chisholm, G.D. (1973) Testicular biopsy in evaluation of male infertility. British Medical Journal 3, 577.

Mroueh, A., Lytton, G. \& Kase, N. (1967) Effects of HCG and HMG (pergonal) in males with oligospermia. Journal of Clinical Endocrinology and Metabolism, 27, 53.

Macleod, J., Pazianos, A. \& RAY, B.S. (1964) Restoration of human spermatogenesis by menopausal gonadotrophins. Lancet, i, 1196.

NeLSON, W.O. (1953) Interpretation of testicular biopsy. Journal of the American Medical Association, 151, 449.

Rowley, M.J. \& Heller, C.G. (1972) The testosterone rebound phenomenon in the treatment of male infertility. Fertility and Sterility, 23, 498.

ScorT, L.S. (1958) The effect of varicocele on spermatogenesis. Proceedings of the Society for the Study of Fertility, 10, 33.

Scotr, L.S. (1961) Varicocele-a treatable cause of subfertility. British Medical Journal, 1, 788.

Spence, A.W. \& Medvei, V.C. (1959) Testosterone in defective spermatogenesis. Lancet, i, 124.

TulLOCH, W.S. (1952) Consideration of sterility factors in the light of subsequent pregnancies: subfertility in the male. Transactions of the Edinburgh Obstetrical Society, 1951-52, p. 29. 